\title{
Model studies toward the synthesis of the bioactive diterpenoid, harringtonolide $\uparrow$
}

\author{
Timothy P. O'Sullivan, ${ }^{* a}$ Hongbin Zhang $^{b}$ and Lewis N. Mander ${ }^{c}$
}

Received 17th May 2007, Accepted 19th June 2007

First published as an Advance Article on the web 2nd July 2007

DOI: $10.1039 / \mathrm{b} 707467 \mathrm{k}$

In model studies towards the synthesis of harringtonolide, the construction of the tropone moiety via arene cyclopropanation was investigated. The installation of the lactone ring was accomplished by way of a Diels-Alder cycloaddition of various indenones and $\alpha$-pyones. The incorporation of the key bridge methyl group and subsequent control of its stereochemistry is also outlined.

\section{Introduction}

The diterpenoid tropone, harringtonolide (3), was first isolated in North America from the seeds of Cephalotaxus harringtonia (Taxaceae) and its structure established by X-ray crystallography (Scheme 1). ${ }^{1}$ It was also isolated in China from C. hainanensi ${ }^{2,3}$ and found to have both anti-neoplastic and anti-viral properties, being active against Lewis Lung carcinoma, Walker carcinoma, Sarcoma-180, and L-1210, L-615 and P-388 leukaemias, as well as showing in vitro activity against influenza type A, Newcastle disease, Japanese B encephalitis and vaccinia viruses. ${ }^{4}$ Harringtonolide is a structurally rigid and congested molecule, consisting of seven adjacent stereocenters. Of particular interest is the presence of the cycloheptatrienone, or tropone, substructure since it is believed that this functionality is responsible for the biological activity of the compound.

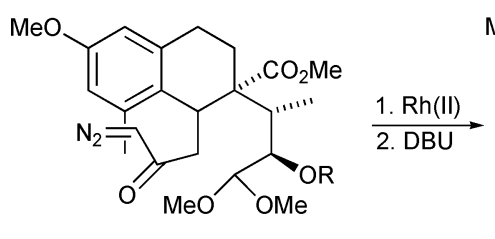

1

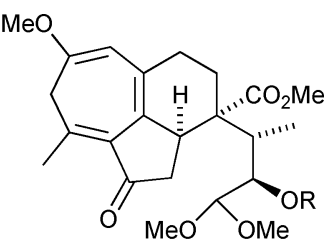

2 8 Steps

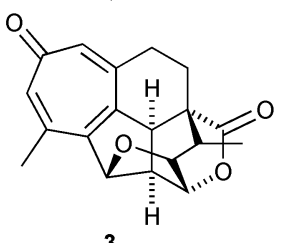

3
Scheme 1 Previous synthesis of harringtonolide.

${ }^{a}$ Department of Chemistry, University College Cork, Cork, Ireland. E-mail: tim.osullivan@ucc.ie; Fax: +35321490 1656; Tel: +353214901655

${ }^{b}$ Key Laboratory of Medicinal Chemistry for Natural Resources, Yunnan University, Kunming, P. R. C. E-mail: zhanghb@ynu.edu.cn; Fax: +86871 5035538; Tel: +868715031119

'Research School of Chemistry, Australian National University, Canberra, Australia.E-mail:mander@rsc.anu.edu.au; Fax:+61 26125 0750; Tel: +61 261253761

$\dagger$ Electronic supplementary information (ESI) available: Additional experimental details. See DOI: 10.1039/b707467k
While we have previously reported the successful synthesis of harringtonolide by way of an arene-cyclopropanation strategy, the approach had some inherent drawbacks. ${ }^{5-7}$ In particular, the relatively early formation of the reactive cycloheptatriene moiety and the need to carry out extensive manipulations in its presence had a deleterious impact on yields. It was clear from these difficulties that an improved route to harringtonolide was required. In this new scheme, the cyclopropanation-tautomerisation process would be effected at a much later stage so that fewer subsequent steps would be required. It was proposed that the lactone function be installed by means of a Diels-Alder cycloaddition reaction, while the ether ring would be established using cyclopropyl ringopening chemistry (Scheme 2). The bulk of the harringtonolide skeleton would thus be in place prior to installation of the cycloheptatriene motif. While the initial $[4+2]$ cycloaddition<smiles>[R]C12C(=O)O[C@@H](CC1C)[C@@H]1C(=O)c3c(C)cc(OC)cc3[C@H]12</smiles><smiles>COc1cc(C)c2c(c1)C=CC2=O</smiles><smiles>[R]c1cccoc1=O</smiles>

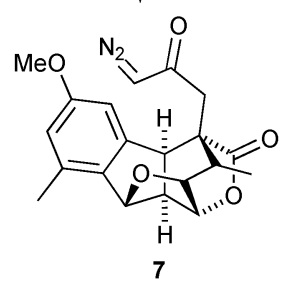
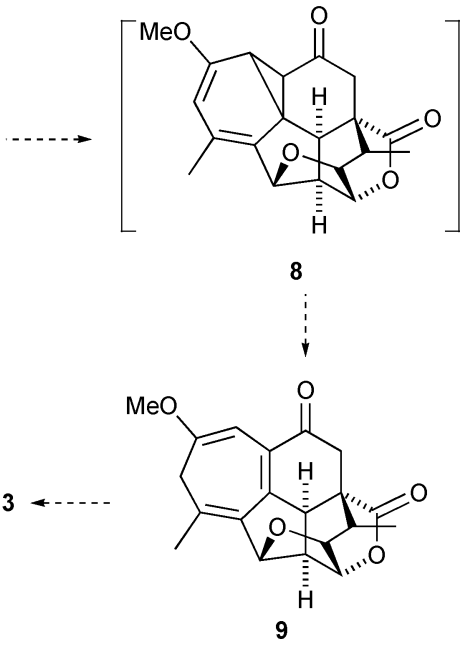

Scheme 2 Proposed route to harringtonolide. 
between the indenone and the pyrone was likely to be problematic, the intramolecular cyclopropanation of the aromatic ring was of greater concern. This crucial step was not expected to be as favourable as the conversion of $\mathbf{1}$ to $\mathbf{2}$ in the previous total synthesis, given the different ring sizes and the potential for competing reactions, such as $\mathrm{CH}$ insertion at the benzylic position and/or ylide formation with the lactone carbonyl group.

\section{Results and discussion}

In order to study this key synthetic step and other aspects of the proposed route to harringtonolide, a series of model studies was initiated. From a geometrical perspective, diazoketone $\mathbf{1 0}$ was considered to be a good match for 7 (Fig. 1). This was supported by some preliminary computational calculations in which both molecules were overlaid for comparison purposes.
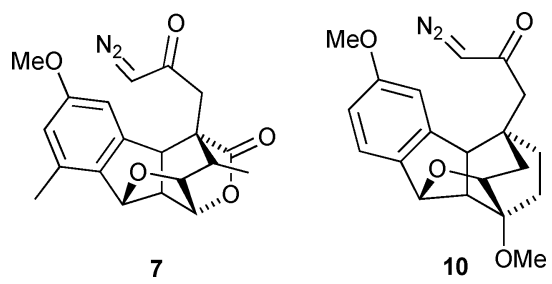

Fig. 1 Molecular geometry comparison.

5-Methoxyindanone (11), ${ }^{8}$ prepared in 2 steps from commercially available $m$-methoxycinnamic acid, was treated with $N$ bromosuccinimide and triethylamine to afford indenone $\mathbf{1 2}$ in $69 \%$ yield (Scheme 3). Birch reduction of $p$-methoxyphenylacetic acid (13) followed by acidification and esterification afforded two isomers $\mathbf{1 4 a}$ and $\mathbf{1 4 b}$ in a $1.5: 1$ ratio.<smiles>COc1ccc2c(c1)CC(CC(C)C)C2=O</smiles><smiles>COc1ccc(CC(=O)O)cc1</smiles>

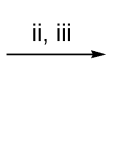

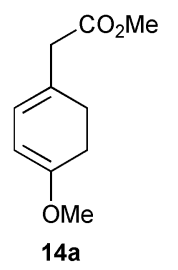

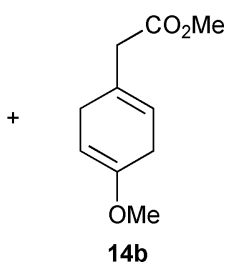

14b
Scheme 3 Reagents and conditions: i, NBS, reflux, $\mathrm{CCl}_{4}$ then $\mathrm{Et}_{3} \mathrm{~N}, 85^{\circ} \mathrm{C}$, $\mathrm{CCl}_{4}, 69 \%$; ii, $\mathrm{Na}, \mathrm{NH}_{3},-33{ }^{\circ} \mathrm{C}$, THF, EtOH; iii, $\mathrm{CH}_{2} \mathrm{~N}_{2}, 0{ }^{\circ} \mathrm{C}, \mathrm{Et}_{2} \mathrm{O}, 67 \%$ overall ( $40 \% \mathbf{1 4 a} ; 27 \% \mathbf{1 4 b})$.

As indenone $\mathbf{1 2}$ was prone to dimerisation at high temperatures or in the presence of Lewis acids, high pressure activation was instead employed for the $[4+2]$ cycloaddition reaction. ${ }^{9}$ When 12 and 14a were subjected to $19 \mathrm{Kbar}$ for $24 \mathrm{~h}$, cycloadduct 15 was obtained as a single product in 52\% yield (Scheme 4). The endo stereochemistry was established by NOE differential spectral analysis of the observed correlations between the protons of the ethane bridge with the cyclopentanone ring protons. Methyl ester $\mathbf{1 5}$ was hydrolysed to afford acid 16, which was submitted<smiles>COC1=CC=C(CC(N)=O)CC1</smiles>
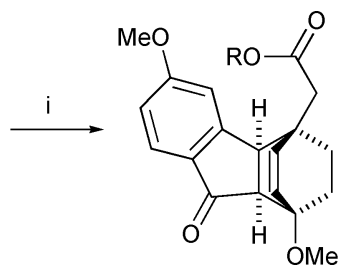

ii

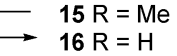

$\downarrow$ iii
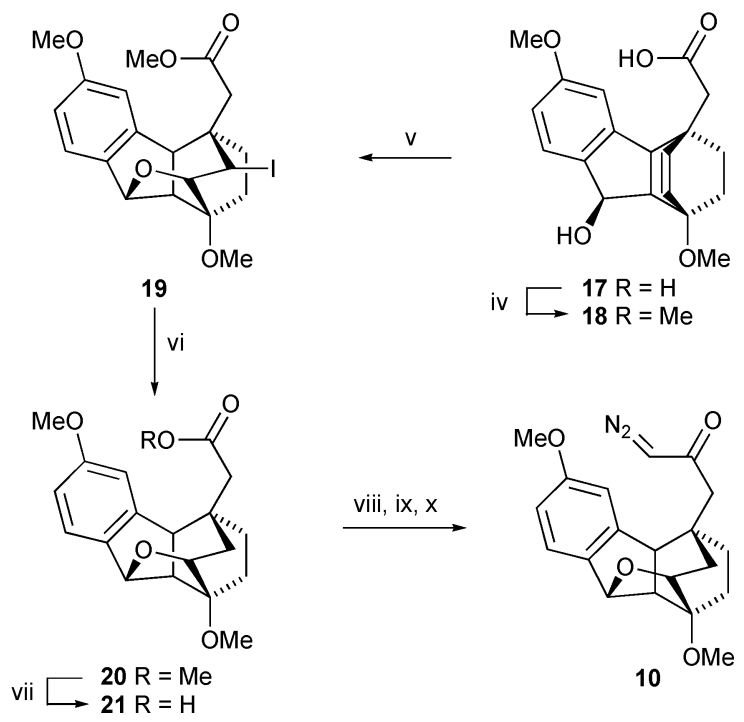

Scheme 4 Reagents and conditions: i, $19 \mathrm{Kbar}$, rt, DCM, 52\%; ii, $\mathrm{KOH}$, rt, $\mathrm{H}_{2} \mathrm{O}$, EtOH, $96 \%$; iii, $\mathrm{LiEt}_{3} \mathrm{BH}, 0{ }^{\circ} \mathrm{C}$, THF; iv, $\mathrm{CH}_{2} \mathrm{~N}_{2}, 0{ }^{\circ} \mathrm{C}, \mathrm{Et}_{2} \mathrm{O}, 90 \%$ overall; v, NIS, rt, THF, 75\%; vi, AIBN, $n$ - $\mathrm{Bu}_{3} \mathrm{SnH}$, reflux, THF, $95 \%$; vii, $\mathrm{KOH}, \mathrm{rt}, \mathrm{H}_{2} \mathrm{O}, \mathrm{EtOH}, 93 \%$; viii, $\mathrm{NaH}$, rt, THF; ix, $(\mathrm{COCl})_{2}, \mathrm{DMF}$, $0{ }^{\circ} \mathrm{C}, \mathrm{THF} ; \mathrm{x}, \mathrm{CH}_{2} \mathrm{~N}_{2}, 0{ }^{\circ} \mathrm{C}, \mathrm{Et}_{2} \mathrm{O}, 75 \%$ overall.

to reduction with lithium triethylborohydride, followed by reesterification with diazomethane. Following iodoetherification, tetrahydrofuran 19 was obtained in $75 \%$ yield over 3 steps from acid 16. The iodide was then subjected to reduction with tri$n$-butyltin hydride furnishing methyl ester 20. Hydrolysis of $\mathbf{2 0}$ produced carboxylic acid $\mathbf{2 1}$ which was subsequently converted to diazoketone $\mathbf{1 0 .}$

Having secured diazoketone 10, we reached the pivotal step for this initial model study. Based on our previous synthesis, rhodium mandelate was chosen as the catalyst for the initial test. Unfortunately, in our model system, these conditions provided $\mathrm{CH}$ insertion compound $\mathbf{2 2}$ as the only isolable product (Scheme 5). A variety of alternative rhodium catalysts, such as $\mathrm{Rh}_{2}(\mathrm{OAc})_{4}$ and $\mathrm{Rh}_{2}(\text { acam })_{4},{ }^{10}$ were similarly unsuccessful. Copper(II) acetylacetonate has proven to be an effective catalyst for the cyclopropanation of aromatic rings, ${ }^{11}$ but it was unsuccessful in this instance. Finally, the desired product was obtained on treatment of diazoketone $\mathbf{1 0}$ with bis( $N$-tert-butylsalicylaldiminato) copper(II). ${ }^{12}$

Having demonstrated that geometrical restraints still permitted cyclopropanation to take place, we next turned our attention to the installation of the lactone-ring framework of the harringtonolide molecule by means of a $[4+2]$ cycloaddition reaction with a suitable pyrone (Scheme 6). A high pressure Diels-Alder reaction 

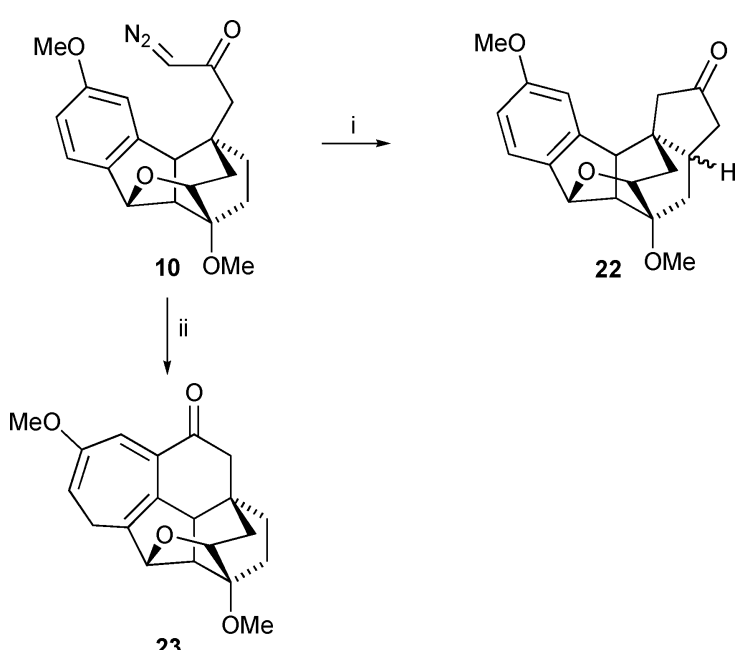

23

Scheme 5 Reagents and conditions: i, Rh(mandelate) ${ }_{4}$, reflux, DCM, 47\% ii, bis( $N$-tert-butylsalicylaldiminato) copper(II), reflux, toluene, $30 \%$.

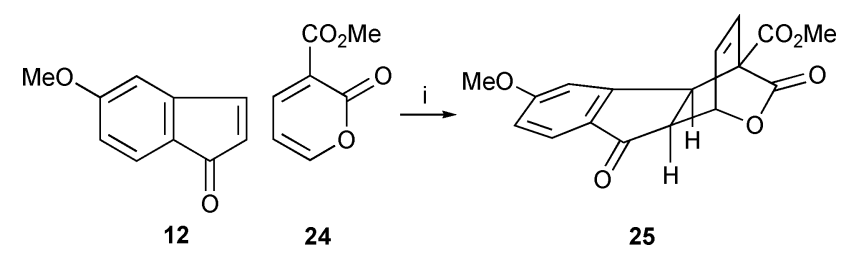

Scheme 6 Reagents and conditions: i, 19 Kbar, rt, DCM, 72\%.

between $\mathbf{1 2}$ and $\mathbf{2 4}$ furnished cycloadduct $\mathbf{2 5}$ as a single product in $72 \%$ yield with the desired endo stereochemistry being confirmed by spectral analysis and X-ray crystallography. ${ }^{13}$

The next phase involved the construction of the internal framework of the molecule. This entailed the formation of an ether bond to introduce the tetrahydrofuran moiety and the incorporation of a bridge methyl group with the correct stereochemistry. Based upon previous work, the prospect of forming the tetrahydrofuran ring in harringtonolide by a process equivalent to $26 \rightarrow 28$ appeared to be feasible (Scheme 7). ${ }^{5}$

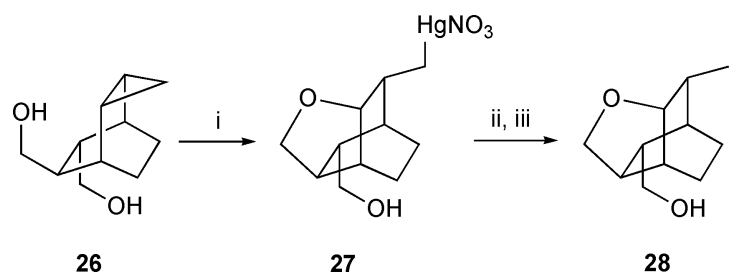

Scheme 7 Reagents and conditions: i, $\mathrm{Hg}\left(\mathrm{NO}_{3}\right)_{2}$; ii, $\mathrm{KBr}$; iii, $\mathrm{NaBH}_{4}$, rt, DME, $80 \%$ overall.

Accordingly, ketone 25 was reduced to benzylic alcohol 29 in $77 \%$ yield (Scheme 8). A combination of diazomethane and a catalytic amount of palladium acetate afforded $\mathbf{3 0}$ in almost quantitative yield. Unfortunately, subsequent mercury-mediated ring-opening was wholly unsuccessful, despite recourse to a wide range of reagents and conditions. Attempted iodoetherification of intermediate $\mathbf{2 9}$ as per $\mathbf{1 8} \rightarrow \mathbf{1 9}$ merely resulted in oxidation of $\mathbf{2 9}$ to ketone precursor 25. Additional work would reveal the olefinic bond in $\mathbf{2 9}$ to be quite unreactive towards an array of different<smiles>COc1ccc2c(c1)C1C(C(=O)O2)C2CCC1(C(C)=O)C(=O)O2</smiles>

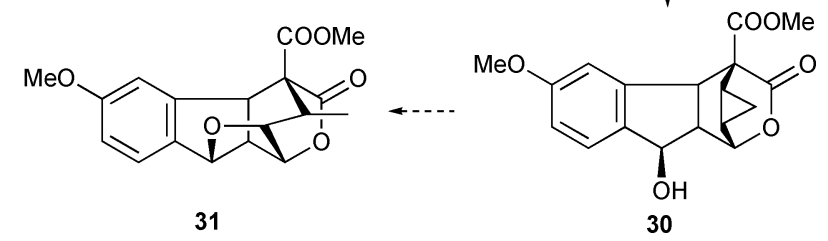

Scheme 8 Reagents and conditions: i, $\mathrm{NaBH}_{4}, \mathrm{rt}, \mathrm{MeOH}, \mathrm{THF}, 77 \%$; ii, $\mathrm{CH}_{2} \mathrm{~N}_{2}, \operatorname{Pd}(\mathrm{OAc})_{2}, 0{ }^{\circ} \mathrm{C}, \mathrm{Et}_{2} \mathrm{O}, 95 \%$.

reagents, most likely a result of the electron-withdrawing nature of the adjacent lactone ring. ${ }^{14}$

In an effort to overcome this unexpected lack of reactivity, we decided to incorporate a methyl group into the 4-position of the pyrone, thereby obviating the need for the cyclopropyl ringopening step entirely and with the additional benefit of increasing the electron density of the olefinic bond of the Diels-Alder adduct. Treating 24 with ethereal diazomethane afforded 32 in $82 \%$ yield (Scheme 9). ${ }^{15}$ When the newly prepared pyrone $\mathbf{3 2}$ and indenone 12 were subjected to high pressure, cycloadduct $\mathbf{3 3}$ was obtained. Elaboration of $\mathbf{3 3}$ posed an interesting challenge. Attack of an electrophilic reagent on the more exposed face of the olefinic bond would position the methyl group over the aromatic ring with the undesired endo stereochemistry. Accordingly, an indirect strategy was employed. Reduction of $\mathbf{3 3}$ to benzylic alcohol $\mathbf{3 4}$ followed by hydroboration-oxidation afforded diol 35 with the methyl substituent in the endo location. Oxidation of 35 with the Dess-Martin periodinane furnished diketone $36 .{ }^{16}$ Treatment of the diketone with a catalytic amount of DBU effected the epimerisation of $\mathbf{3 6}$ to the thermodynamic product $\mathbf{3 7}$ with the methyl group now adopting the requisite exo stereochemistry. The transformation of $\mathbf{3 6}$ to $\mathbf{3 7}$ was manifestly apparent from the ${ }^{1} \mathrm{H}$ NMR spectrum. The bridge methyl, which had appeared as a doublet at $\delta 0.49$ in 36, now had a chemical shift of $\delta 1.35$ in 37. This large downfield shift can be ascribed to the removal of the methyl group from the shielding effect of the aromatic ring. Reduction of diketone 37 afforded syn diol 38. Treatment of $\mathbf{3 8}$ with $p$ toluenesulfonic acid led to formation of the benzylic cation and trapping by the remaining hydroxyl to install the tetrahydrofuran ring system (31).

Demethylation of $\mathbf{3 1}$ was accomplished by the method of Fujita et al. using a combination of aluminium tribromide and tetrahydrothiophene (Scheme 10). ${ }^{17}$ Compound 39 was then converted to the corresponding acid chloride which was immediately reduced to primary alcohol 40. Following oxidation of the carbinol to 41, the aldehyde was added to an excess of the methoxymethylene ylide thereby producing $(Z)$-methylenol ether $\mathbf{4 2}$ in $58 \%$ yield. The enol ether was hydrolysed to the homologated aldehyde $\mathbf{4 3}$ and then oxidised to carboxylic acid $\mathbf{4 4}$. The acid chloride, generated by addition of the Vilsmeier reagent to a benzene solution of $\mathbf{4 4}$, was converted in situ to diazoketone $\mathbf{4 5}$ with ethereal diazomethane. A strong band at $2106 \mathrm{~cm}^{-1}$ in the IR spectrum was characteristic of 


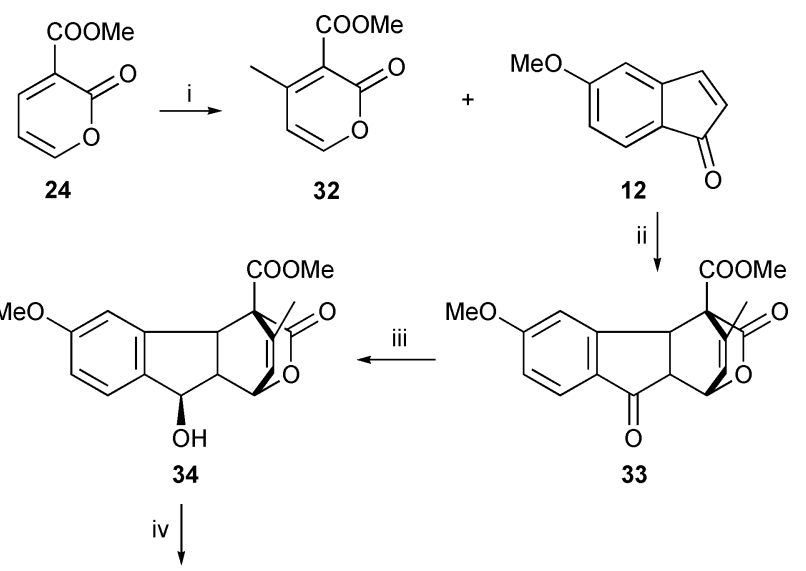

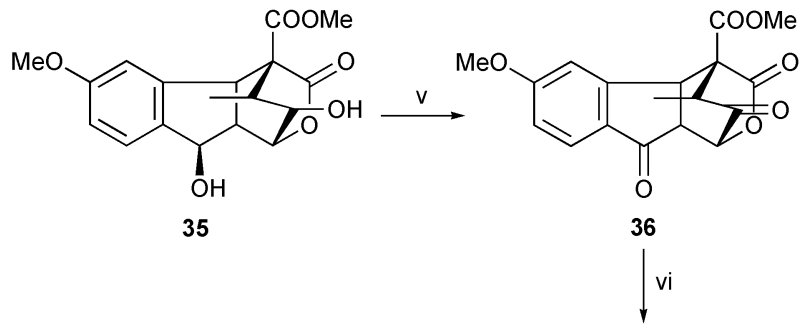

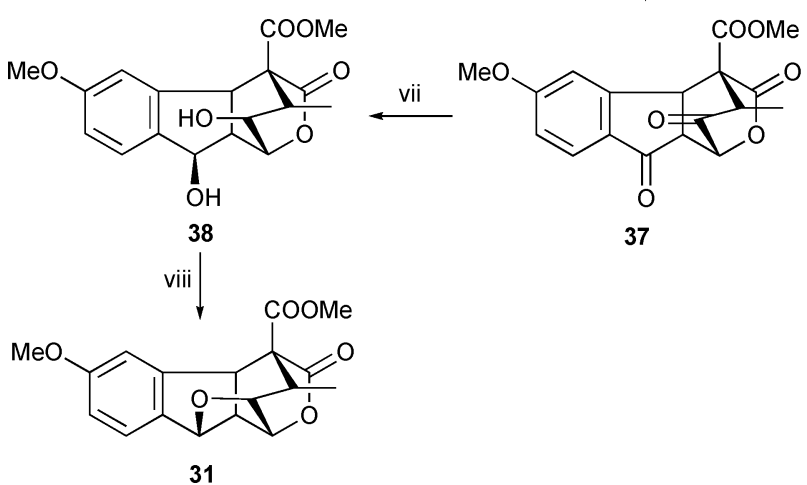

Scheme 9 Reagents and conditions: i, $\mathrm{CH}_{2} \mathrm{~N}_{2}, 0{ }^{\circ} \mathrm{C}, \mathrm{DCM}, 82 \%$, ii, $19 \mathrm{Kbar}$, rt, DCM, 73\%; iii $\mathrm{NaBH}_{4}$, rt, $\mathrm{MeOH}$, THF, 85\%; iv, $\mathrm{BH}_{3} \cdot \mathrm{DMS}$, $0{ }^{\circ} \mathrm{C}$, THF then $\mathrm{Et}_{3} \mathrm{NO}$, reflux, THF, $49 \%$; v, DMP, rt, $t \mathrm{BuOH}$, THF, $48 \%$; vi, DBU, rt, THF, 72\%; vii, $\mathrm{NaBH}_{4}$, rt, $\mathrm{MeOH}, \mathrm{THF}, 66 \%$; viii, $p$-TsOH, THF, $71 \%$.

the asymmetric diazo stretch while a molecular ion of $\mathrm{m} / z 354$ was accompanied by a fragmentation pattern showing loss of nitrogen to produce a peak at $m / z 328$.

Heating diazoketone $\mathbf{4 5}$ in the presence of bis $(N$-tertbutylsalicylaldiminato) copper(II) resulted in a complex mixture of products. Unfortunately, it was evident from the ${ }^{1} \mathrm{H}-\mathrm{NMR}$ spectrum that no arene cyclopropanation had taken place. Neither the use of $\mathrm{Cu}(\mathrm{acac})_{2}$ nor of $\mathrm{Rh}(\mathrm{OAc})_{2}$ was successful - both catalysts merely produced a complex mixture of aromatic compounds. The most likely explanation for the failure of the arene cyclopropanation sequence involves carbonyl ylide formation with the lactone ring. ${ }^{18,19}$ Masking of carbonyls as ortho acetals has previously been used to circumvent ylide formation. ${ }^{20}$ Accordingly, acid 44 was protected as the methyl ester 46 using diazomethane. Regrettably, we were unable to transform 46 to the corresponding ortho acetal derivative. Even powerful reagents such as the Meerwein salt method ${ }^{21}$ or Noyori's method ${ }^{22}$ failed to effect the desired transformation.

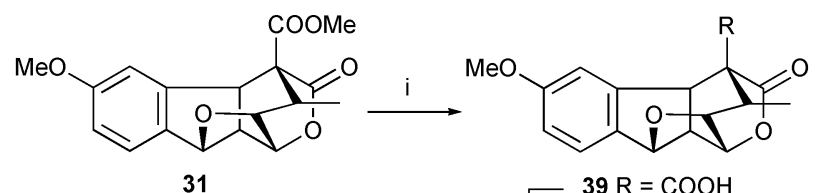

31

ii $\quad 39 \mathrm{R}=\mathrm{COOH}$

$\longrightarrow 40 \mathrm{R}=\mathrm{CH}_{2} \mathrm{OH}$

iii $\longrightarrow 41 \mathrm{R}=\mathrm{CHO}$

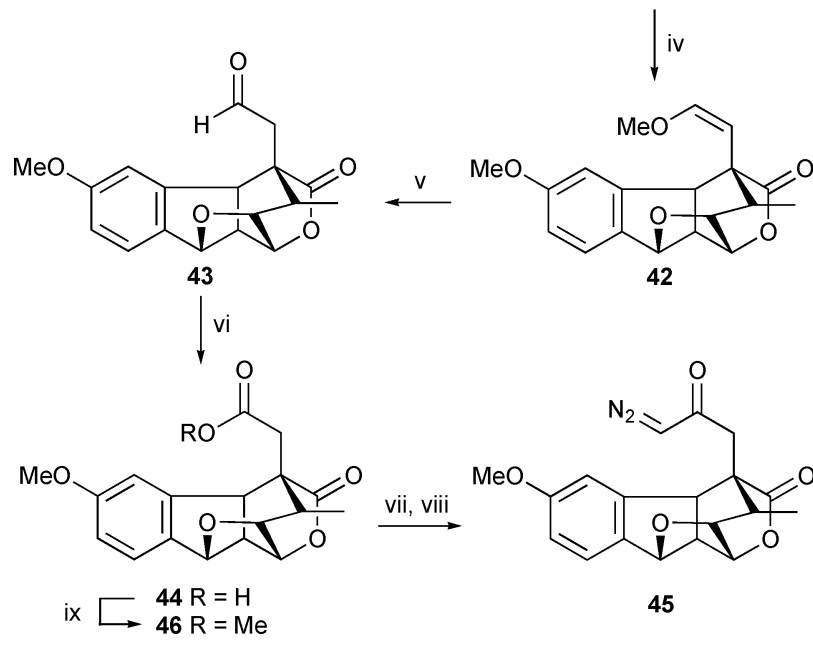

Scheme 10 Reagents and conditions: i, tetrahydrothiophene, $\mathrm{AlBr}_{3}, 0{ }^{\circ} \mathrm{C}$, $\mathrm{DCM}, 69 \%$; ii $(\mathrm{COCl})_{2}$, DMF, $0{ }^{\circ} \mathrm{C}$, benzene then $\mathrm{NaBH}_{4}, 0{ }^{\circ} \mathrm{C}$, THF, $71 \%$; iii, DMP, rt, $t \mathrm{BuOH}$, THF, 92\%; iv, $\left[\mathrm{Ph}_{3} \mathrm{PCH}_{2} \mathrm{OMe}\right] \mathrm{Cl}$, LiHMDS, $0{ }^{\circ} \mathrm{C}$, THF, $58 \%$; v, $\mathrm{HCl}$, rt, $\mathrm{H}_{2} \mathrm{O}$, THF, $83 \%$; vi, $\mathrm{NaClO}_{2}, \mathrm{H}_{2} \mathrm{O}_{2}, 0{ }^{\circ} \mathrm{C}, \mathrm{H}_{2} \mathrm{O}$, $\mathrm{ACN}, 65 \%$; vii, $(\mathrm{COCl})_{2}, \mathrm{DMF}, 0{ }^{\circ} \mathrm{C}$, benzene; viii, $\mathrm{CH}_{2} \mathrm{~N}_{2}, 0{ }^{\circ} \mathrm{C}, \mathrm{Et}_{2} \mathrm{O}$, $62 \%$ overall; ix, $\mathrm{CH}_{2} \mathrm{~N}_{2}, 0{ }^{\circ} \mathrm{C}, \mathrm{Et}_{2} \mathrm{O}, 96 \%$.

At this point, we opted to revise our synthetic approach. First, we would incorporate the C8 methyl, which corresponds to the tropone methyl substituent, into the indenone intermediate. Secondly, we would seek to increase the reactivity of the olefinic bond in the cycloadduct by reducing the carboxyl group at an early stage in the synthetic plan. Finally, we would investigate the feasibility of blocking unwanted ylide formation by reduction of the lactone and subsequent protection of the resultant lactol.

Demethylation of $\mathbf{3 2}$ to carboxylic acid $\mathbf{4 7}$ by in situ generation of trimethylsilyl iodide proceeded well (Scheme 11). Meanwhile, bromination of indanone 48, a known compound, ${ }^{23}$ and subsequent elimination afforded indenone 4 in $63 \%$ yield. Once again, a high pressure Diels-Alder reaction between $\mathbf{4 7}$ and $\mathbf{4}$ furnished cycloadduct 49 with the required regio- and stereochemistry. Compound 49 was converted to the corresponding acid chloride and then reduced to carbinol 50. This alcohol was subsequently protected as the tert-butyldimethyl silyl ether $\mathbf{5 1}$ in good yield.

Applying the previously established methodology, ketone 51 was reduced to the benzylic alcohol $\mathbf{5 2}$ and, following hydroborationoxidation of the olefinic bond, diol $\mathbf{5 3}$ was oxidised to diketone 54 (Scheme 12). Treatment of 54 with a catalytic amount of DBU afforded epimer $\mathbf{5 5}$ in $98 \%$ yield. Interestingly, while the epimerisation of $\mathbf{3 6}$ to $\mathbf{3 7}$ had provided a $1: 3$ ratio of endo : exo products, conversion of $\mathbf{5 4}$ to $\mathbf{5 5}$ went to completion with no starting material remaining. This unexpected result is presumably due to the bulky TBDMS ether side chain, which favours the thermodynamic product through steric interaction. Indeed, MM2 calculations suggest a $2.01 \mathrm{kcal} \mathrm{mol}^{-1}$ energy difference between 
<smiles>CC(=O)c1c(C)ccoc1=O</smiles>

32

i<smiles>Cc1cc[se]c(=O)c1C(=O)O</smiles>

47<smiles>COc1cc(C)c2c(c1)CCC2=O</smiles>

48

ii<smiles>COc1cc(C)c2c(c1)C=CC2=O</smiles><smiles>[R]CC12CCC(C(C)C)(OC1=O)C1C(=O)c3c(C)cc(OC)cc3C12</smiles>

$\begin{aligned} \mathrm{v} \longrightarrow 50 \mathrm{R} & =\mathrm{OH} \\ 51 \mathrm{R} & =\mathrm{OTBDMS}\end{aligned}$
Scheme 11 Reagents and conditions: $\mathrm{i}, \mathrm{I}_{2},\left(\mathrm{SiMe}_{3}\right)_{2}$, reflux, $\mathrm{CHCl}_{3}, 75 \%$; i, NBS, reflux, $\mathrm{CCl}_{4}$ then $\mathrm{Et}_{3} \mathrm{~N}, 85^{\circ} \mathrm{C}, \mathrm{CCl}_{4}, 63 \%$; iii, $19 \mathrm{Kbar}$, rt, DCM, $68 \%$; iv, $(\mathrm{COCl})_{2}$, DMF, $0{ }^{\circ} \mathrm{C}$, THF then $\mathrm{NaBH}_{4}, 0{ }^{\circ} \mathrm{C}$, THF, $66 \%$; v, TBDMSOTf, $N, N$-diisopropylethylamine, $0{ }^{\circ} \mathrm{C}$, DCM, $83 \%$.

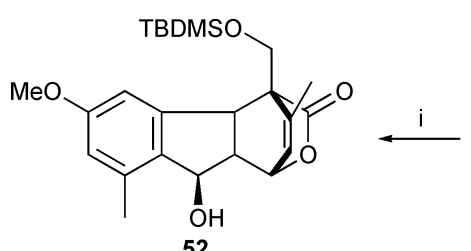

52

ii

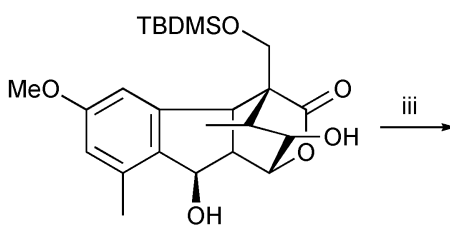

53

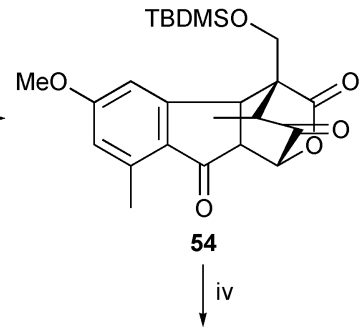

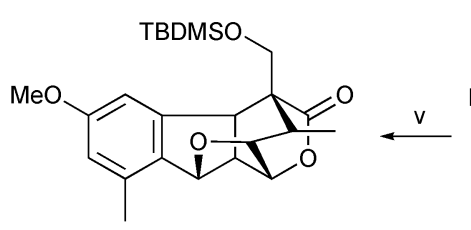

56

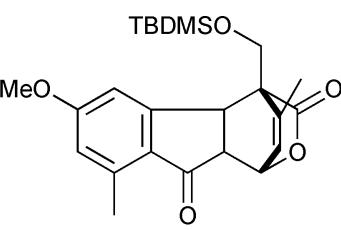

51

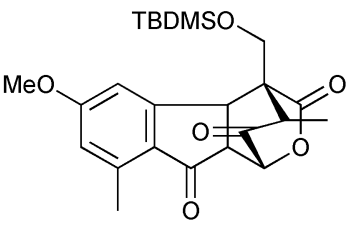

55
Scheme 12 Reagents and conditions: i $\mathrm{NaBH}_{4}, \mathrm{rt}, \mathrm{MeOH}, \mathrm{THF}, 89 \%$; ii, $\mathrm{BH}_{3} \cdot \mathrm{DMS}, 0{ }^{\circ} \mathrm{C}$, THF then $\mathrm{Et}_{3} \mathrm{NO}$, reflux, THF, $38 \%$; iii, DMP, rt, $t \mathrm{BuOH}$, THF, 58\%; iv, DBU, rt, THF, 98\%; v, $\mathrm{NaBH}_{4}$, rt, $\mathrm{MeOH}$, THF then $\mathrm{HCl}$ work-up, $64 \%$.

54 and 55 as compared to a gap of only $0.29 \mathrm{kcal} \mathrm{mol}^{-1}$ between $\mathbf{3 6}$ and $\mathbf{3 7}$. Reduction of $\mathbf{5 5}$, followed by acidic work-up, afforded ether 56 in 64\% yield.
Finally, we proposed reducing the lactone to the corresponding lactol, followed by masking of the resultant hydroxyl with a bulkly protecting group, namely a TBDMS ether. The reason for the introduction of this group was twofold - first, to block any reaction between the carbenoid and the free hydroxyl and secondly, to direct the carbenoid towards the aromatic ring. Previous studies on gibberellin intermediates had demonstrated that a DIBAL reduction could be conducted in the presence of a dichloroacetate protecting group. ${ }^{24} \mathrm{With}$ this information in mind, we returned to substrate 56 and the TBDMS ether was cleaved with tetrabutylammonium fluoride to afford the primary alcohol $\mathbf{5 7}$, which was then reprotected as the dichloroacetate $\mathbf{5 8}$ (Scheme 13). Reduction of 58 with DIBAL at $-40{ }^{\circ} \mathrm{C}$ furnished the desired hemi-acetal 59 in $57 \%$ yield. Protection of the hemi-acetal as the TBDMS ether $\mathbf{6 0}$ proceeded readily while subsequent hydrolysis of the acetate ester furnished advanced intermediate $\mathbf{6 1}$.

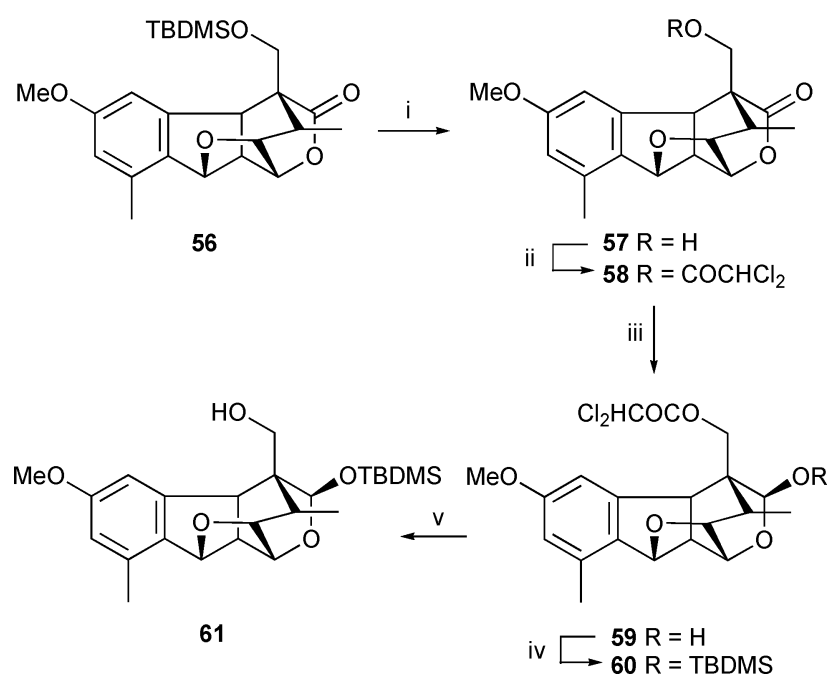

Scheme 13 Reagents and conditions: i, TBAF, rt, THF, 95\%; ii, dichloroacetyl chloride, pyridine, rt, DCM, $96 \%$; iii, DIBAL-H, $-40{ }^{\circ} \mathrm{C}$, toluene, $57 \%$; iv, TBDMSOTf, $N, N$-diisopropylethylamine, rt, DCM, $72 \%$; $\mathrm{Et}_{3} \mathrm{~N}$, rt, $\mathrm{H}_{2} \mathrm{O}, \mathrm{MeOH}, 90 \%$.

\section{Conclusions}

These preliminary model studies have allowed us to investigate the feasibility of a more concise route to the complex diterpenoid, harringtonolide. While our initial studies demonstrated that the geometry of the molecule is suitable for arene-cyclopropanation purporse, we have also uncovered a number of unforeseen obstacles. In particular, the low reactivity of the olefinic bond of the Diels-Alder cycloadduct and the propensity of the $\alpha$-diazoketone intermediate to undergo unwanted ylide formation with the lactone ring moiety were problematical. We have successfully incorporated the bridge methyl substituent via the pyrone starting material and have controlled its stereochemical orientation in subsequent work.

Finally, we have modified the chemistry of the lactone ring and incorporated a bulky protecting group in the expectation of blocking ylide formation and directing cyclopropanation towards the aromatic ring. We hope to report on our work on the remaining steps (Scheme 14) and the completion of this synthesis in due course. 


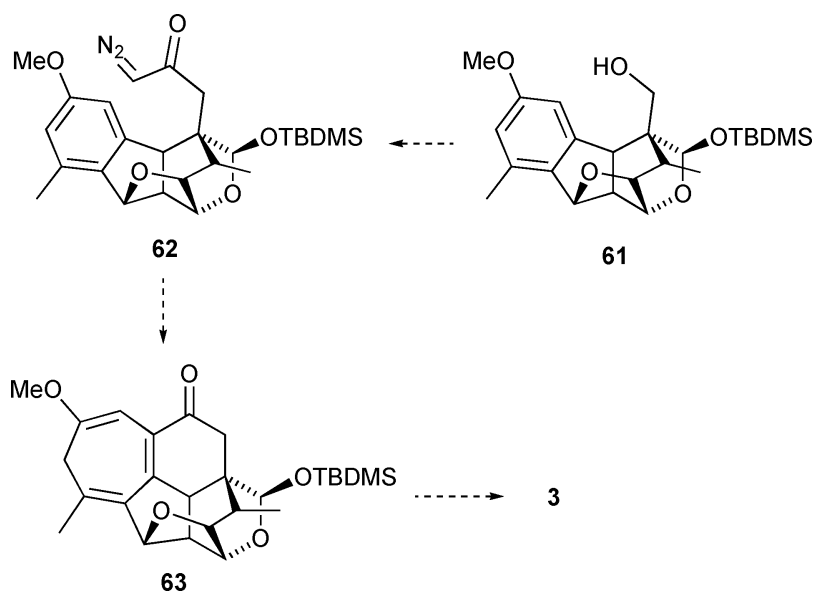

Scheme 14 Remaining steps in the synthesis of harringtonolide.

\section{Experimental}

\section{General experimental}

Starting materials and reagents used in reactions were obtained commercially and were used without purification, unless otherwise indicated. Flash chromatography was conducted with Merck Kieselgel 60 silica gel as the adsorbent. Proton nuclear magnetic resonance $\left({ }^{1} \mathrm{H} \mathrm{NMR}\right)$ spectra were recorded on a Varian Gemini 300 spectrometer at $300 \mathrm{MHz}$. Carbon-13 nuclear magnetic resonance $\left({ }^{13} \mathrm{C} \mathrm{NMR}\right)$ were recorded on Varian Gemini 300 spectrometer at $75.5 \mathrm{MHz}$. Infrared (IR) spectra $\left(v_{\max }\right)$ were recorded on a Perkin-Elmer 683 Infrared spectrophotometer in $0.25 \mathrm{~mm} \mathrm{NaCl}$ solution cells or recorded on a Perkin-Elmer 1800 Fourier Transform Infrared spectrophotometer in $\mathrm{KBr}$ plates. Low resolution EI mass (LRMS) spectra $(70 \mathrm{eV})$ and high resolution accurate mass measurements (HRMS) were recorded on a VG Autospec double focussing mass spectrometer. Melting points (mp) were recorded on a Reichert hot-stage and are uncorrected. Microanalyses were conducted by the Australian National University Analytical Services Unit, Canberra.

\section{5-Methoxyindenone (12)}

$\mathrm{N}$-Bromosuccinimide ( $356 \mathrm{mg}, 2 \mathrm{mmol}$ ) was added to a solution of the indanone 11 (324 mg, $2 \mathrm{mmol})$ in carbon tetrachloride $(50 \mathrm{ml})$. The resulting suspension was stirred at reflux with irradiation from a tungsten lamp for 2 hours. Triethylamine $(1 \mathrm{ml})$ was added, then the reaction mixture was stirred at $85{ }^{\circ} \mathrm{C}$ (oil bath) for a further 2 hours. The mixture was filtered through a short column of silica gel and washed with petroleum ether $40-60{ }^{\circ} \mathrm{C}$ : ethyl acetate $=1: 1$. The solvent was removed under reduced pressure and the residue was purified by flash chromatography on silica gel (petroleum ether $40-60{ }^{\circ} \mathrm{C}:$ ethyl acetate $=10: 1 \rightarrow 2: 1$ ) to afford 5-methoxyindenone (12) $(218 \mathrm{mg}, 69 \%)$ as a yellow oil; $v_{\max } / \mathrm{cm}^{-1}$ 3005 (ArH), $1707(\mathrm{C}=\mathrm{O}), 1251\left(\mathrm{ArOCH}_{3}\right), 1230(\mathrm{CC}=\mathrm{OC}), 1037$ $\left(\mathrm{ArOCH}_{3}\right) ; \delta_{\mathrm{H}}\left(300 \mathrm{MHz}, \mathrm{CDCl}_{3}\right) 7.40(1 \mathrm{H}, \mathrm{d}, J=5.8 \mathrm{~Hz}, \mathrm{H}-3)$, $7.36(1 \mathrm{H}, \mathrm{d}, J=7.7 \mathrm{~Hz}, \mathrm{H}-7), 6.59(1 \mathrm{H}, \mathrm{d}, J=2.2 \mathrm{~Hz}, \mathrm{H}-4), 6.58$ $(1 \mathrm{H}, \mathrm{dd}, J=2.2, J=7.7 \mathrm{~Hz}, \mathrm{H}-6), 5.87(1 \mathrm{H}, \mathrm{d}, J=5.8 \mathrm{~Hz}, \mathrm{H}-2)$, $3.82\left(3 \mathrm{H}, \mathrm{s}, \mathrm{CH}_{3} \mathrm{O}\right) ; \delta_{\mathrm{C}}\left(75 \mathrm{MHz}, \mathrm{CDCl}_{3}\right) 196.88(\mathrm{C} 1), 164.37$ (C5), 147.52 (C3), 147.10 (C3a), 128.65 (C2), 124.28 (C7), 122.87 (C7a), 110.97 (C6), $110.36(\mathrm{C} 4), 55.53\left(\mathrm{CH}_{3} \mathrm{O}\right) ; \mathrm{m} / \mathrm{z} 160\left(\mathrm{M}^{+}, 40 \%\right), 145$
(2), 132 (10), 117 (18), 106 (12), 89 (87), 78 (5), 74 (28), 70 (68), 66 (10), 61 (100).

\section{Methyl-2-(1'-methoxycyclohexa-1',3'-dienyl)ethanoate (14a) and methyl-2-(1'-methoxycyclohexa-1',4'-dienyl)ethanoate (14b)}

Liquid ammonia $(150 \mathrm{ml})$ was added to a solution of 2-(4'methoxybenzene)ethanoic acid (13) (3.32 g, $20 \mathrm{mmol})$ in ethanol $(10 \mathrm{ml})$ and THF (20 ml). Sodium (metal, $3.2 \mathrm{~g}, 140 \mathrm{mmol}, 7$ eq.) was added in small pieces over a period of approximately $1 \mathrm{~h}$ until the blue colour persisted for $4 \mathrm{~min}$. The ammonia was allowed to evaporate overnight. Ice $(200 \mathrm{~g})$ was added to the residue. The resulting mixture was acidified with $1 \mathrm{M} \mathrm{HCl}(\mathrm{pH}=5)$, and then extracted with ethyl acetate $(4 \times 80 \mathrm{ml})$. The combined organic phase was washed with water $(2 \times 40 \mathrm{ml})$, brine $(40 \mathrm{ml})$ and dried over sodium sulfate. After filtration, the solvent was removed under reduced pressure and the residue was treated with ethereal diazomethane at $0{ }^{\circ} \mathrm{C}$. After removal of the solvent, the residue was purified by flash chromatography on silica gel (petroleum ether $40-60{ }^{\circ} \mathrm{C}:$ ethyl acetate $\left.=100: 1 \rightarrow 20: 1 \rightarrow 10: 1\right)$ to afford an inseparable mixture of the methyl esters $(\mathbf{1 4 a}: \mathbf{1 4 b}=1.5: 1 ; 2.46 \mathrm{~g}$, $67 \%$ ) as a pale yellow oil.

Methyl-2-(1'-methoxycyclohexa-1', 3'-dienyl)ethanoate (14a). $\delta_{\mathrm{H}}\left(300 \mathrm{MHz}, \mathrm{CDCl}_{3}\right) 5.69(1 \mathrm{H}, \mathrm{d}, J=6.0 \mathrm{~Hz}, H-\mathrm{C}=\mathrm{C}), 4.85$ $\left(1 \mathrm{H}, \mathrm{d}, J=6.1 \mathrm{~Hz}, H-\mathrm{C}=\mathrm{C}-\mathrm{OCH}_{3}\right), 3.62\left(3 \mathrm{H}, \mathrm{s}, \mathrm{OCH}_{3}\right), 3.52$ $\left(3 \mathrm{H}, \mathrm{s}, \mathrm{OCH}_{3}\right), 3.01(2 \mathrm{H}, \mathrm{m}), 2.72(2 \mathrm{H}, \mathrm{m}), 2.25(2 \mathrm{H}, \mathrm{s}, 2 \times \mathrm{H}-2)$.

Methyl-2-(1'-methoxycyclohexa-1', $\mathbf{4}^{\prime}$-dienyl)ethanoate (14b). $\delta_{\mathrm{H}}\left(300 \mathrm{MHz}, \mathrm{CDCl}_{3}\right) 5.50(1 \mathrm{H}, \mathrm{m}, H-\mathrm{C}=\mathrm{C}), 4.55(1 \mathrm{H}, \mathrm{m}$, $\left.H-\mathrm{C}=\mathrm{C}-\mathrm{OCH}_{3}\right), 3.62\left(3 \mathrm{H}, \mathrm{s}, \mathrm{OCH}_{3}\right), 3.49\left(3 \mathrm{H}, \mathrm{s}, \mathrm{OCH}_{3}\right), 2.96$ $(2 \mathrm{H}, \mathrm{m}), 2.72(1 \mathrm{H}, \mathrm{m}), 2.25(2 \mathrm{H}, \mathrm{s}, 2 \times \mathrm{H}-2), 1.95(1 \mathrm{H}, \mathrm{m})$.

\section{(1RS,4SR,4a $R S, 9 \mathrm{a} S R)-1,6$-Dimethoxy-4-methoxycarbonyl- methyl-9-oxo-4,4a,9,9a-tetrahydro-1,4-ethano-1 $H$-fluorene (15)}

The indenone 12 (160 mg, $1 \mathrm{mmol})$ and a mixture of dienes 14a and 14b (364 mg, $2 \mathrm{mmol}$ ) were dissolved in dichloromethane $(1 \mathrm{ml})$ under nitrogen. The reaction mixture was then subjected to high pressure $(19 \mathrm{Kbar}$ ) for $2.5 \mathrm{~h}$. The resulting mixture was purified by flash chromatography on silica gel (petroleum ether $40-60{ }^{\circ} \mathrm{C}$ : ethyl acetate $\left.=10: 1 \rightarrow 5: 1 \rightarrow 1: 1\right)$ to afford the cycloadduct 15 (178 mg, $52 \%$, based on indenone) as white needles; mp 139-140 ${ }^{\circ} \mathrm{C}$ (from EtOAc); found: C, 70.18\%; H, 6.35\%. Calc. for $\mathrm{C}_{20} \mathrm{H}_{22} \mathrm{O}_{5}$ : C, 70.16\%; H, 6.48\%; $v_{\max } / \mathrm{cm}^{-1} 3030$ (ArH), 2950 $(\mathrm{CH}), 1760(\mathrm{C}=\mathrm{O}), 1700(\mathrm{C}=\mathrm{O}), 1255\left(\mathrm{ArOCH}_{3}\right), 1090(\mathrm{C}-\mathrm{O})$, $1030\left(\mathrm{ArOCH}_{3}\right) ; \delta_{\mathrm{H}}\left(300 \mathrm{MHz}, \mathrm{CDCl}_{3}\right) 7.63(1 \mathrm{H}, \mathrm{d}, J=8.5 \mathrm{~Hz}$, $\mathrm{H}-8), 7.08(1 \mathrm{H}, \mathrm{d}, J=2.1 \mathrm{~Hz}, \mathrm{H}-5), 6.87(1 \mathrm{H}, \mathrm{dd}, J=2.2, J=$ $8.6 \mathrm{~Hz}, \mathrm{H}-7), 6.04(1 \mathrm{H}, \mathrm{d}, J=8.7 \mathrm{~Hz}, \mathrm{H}-2), 5.42(1 \mathrm{H}, \mathrm{d}, J=$ $8.7 \mathrm{~Hz}, \mathrm{H}-3), 3.85\left(3 \mathrm{H}, \mathrm{s}, \mathrm{CH}_{3} \mathrm{O}-\mathrm{C} 6\right), 3.74\left(3 \mathrm{H}, \mathrm{s}, \mathrm{COOCH}_{3}\right), 3.55$ $(1 \mathrm{H}, \mathrm{d}, J=7.1 \mathrm{~Hz}, \mathrm{H}-4 \mathrm{a}), 3.52\left(3 \mathrm{H}, \mathrm{s}, \mathrm{CH} \mathrm{H}_{3} \mathrm{O}-\mathrm{C} 1\right), 3.00(1 \mathrm{H}, \mathrm{d}$, $J=7.1 \mathrm{~Hz}, \mathrm{H} 9 \mathrm{a}), 2.95(1 \mathrm{H}, \mathrm{d}, J=15.0 \mathrm{~Hz}, \mathrm{H}-12 \mathrm{~A}), 2.78(1 \mathrm{H}, \mathrm{d}$, $J=15.0 \mathrm{~Hz}, \mathrm{H}-12 \mathrm{~B}), 1.99-1.84$ (2H, m, H-10 $\alpha, \mathrm{H}-11 \alpha), 1.62-1.42$ $(2 \mathrm{H}, \mathrm{m}, \mathrm{H}-10 \beta, \mathrm{H}-11 \beta) ; \delta_{\mathrm{C}}\left(75 \mathrm{MHz}, \mathrm{CDCl}_{3}\right) 202.20$ (C9), 71.95 (COO), 164.55 (C6), 156.21 (C4b), 133.86 (C2), 132.91 (C8a), 131.76 (C3), 125.27 (C8), 114.98 (C7), 111.07 (C5), 79.28 (C1), $55.59\left(\mathrm{CH}_{3} \mathrm{O}-\mathrm{C}_{6}\right), 52.58(\mathrm{C} 9 \mathrm{a}), 51.64\left(\mathrm{COOCH}_{3}\right), 50.84\left(\mathrm{CH}_{3} \mathrm{O}-\right.$ C1), 46.62 (C4a), 40.41 (C4), 40.11 (C12), 31.01 (C10), 28.30 (C11); $\mathrm{m} / \mathrm{z} 342\left(\mathrm{M}^{+}, 5 \%\right), 311$ (12), 279 (3), 269 (15), 254 (6), 241 (30), 
227 (4), 195 (4), 182 (100), 161 (8), 149 (27), 134 (7), 123 (69), 109 (20), 91 (17), 77 (13).

(1RS,4SR,4a $R S, 9 \mathrm{a} S R)-4-C a r b o x y m e t h y l-1,6-d i m e t h o x y-9-0 x 0-$ 4,4a,9,9a-tetrahydro-1,4-ethano- $1 H$-fluorene (16)

The methyl ester 15 (410 mg, $1.2 \mathrm{mmol})$ and potassium hydroxide ( $1.01 \mathrm{~g}, 18 \mathrm{mmol}, 15$ eq.) were dissolved in ethanol $(25 \mathrm{ml})$ and water $(5 \mathrm{ml})$. The reaction mixture was stirred at room temperature for $2 \mathrm{~h}$. Ice $(100 \mathrm{~g})$ was added, then acidified with $1 \mathrm{M} \mathrm{HCl}(20 \mathrm{ml})$ and extracted with chloroform $(5 \times 25 \mathrm{ml})$. The combined organic phase was dried over sodium sulfate. After filtration, the solvent was removed under reduced pressure and the residue was purified by flash chromatography on silica gel (petroleum ether $40-60{ }^{\circ} \mathrm{C}$ : ethyl acetate $=2: 3 \rightarrow 0: 1 \rightarrow \mathrm{DCM}: \mathrm{MeOH}=10: 1 \rightarrow 5: 1)$ to afford the acid $\mathbf{1 6}(380 \mathrm{mg}, 96.4 \%)$, after recrystallisation from ethyl acetate, as colourless needles; mp $221-222^{\circ} \mathrm{C}$ (from EtOAc); found: $\mathrm{C}, 69.43 \%$; H, 6.15\%. Calc. for $\mathrm{C}_{19} \mathrm{H}_{20} \mathrm{O}_{5}$ : C, 69.50\%; $\mathrm{H}$, $6.14 \% ; v_{\max } / \mathrm{cm}^{-1} 3500(\mathrm{COOH}), 3020(\mathrm{ArH}), 2940(\mathrm{CH}), 1700$ $(\mathrm{C}=\mathrm{O}), 1260\left(\mathrm{ArOCH}_{3}\right), 1090(\mathrm{C}-\mathrm{O}) ; \delta_{\mathrm{H}}\left(300 \mathrm{MHz}, \mathrm{CDCl}_{3}\right) 7.67$ $(1 \mathrm{H}, \mathrm{d}, J=8.5 \mathrm{~Hz}, \mathrm{H}-8), 7.07(1 \mathrm{H}, \mathrm{d}, J=2.1 \mathrm{~Hz}, \mathrm{H}-5), 6.90(1 \mathrm{H}$, $\mathrm{dd}, J=2.1, J=8.5 \mathrm{~Hz}, \mathrm{H}-7), 6.08(1 \mathrm{H}, \mathrm{d}, J=8.7 \mathrm{~Hz}, \mathrm{H}-2), 5.45$ $(1 \mathrm{H}, \mathrm{d}, J=8.7 \mathrm{~Hz}, \mathrm{H}-3), 3.87\left(3 \mathrm{H}, \mathrm{s}, \mathrm{CH}_{3} \mathrm{O}-\mathrm{C} 6\right), 3.62(1 \mathrm{H}, \mathrm{d}, J=$ $7.0 \mathrm{~Hz}, \mathrm{H}-4 \mathrm{a}), 3.54\left(3 \mathrm{H}, \mathrm{s}, \mathrm{CH}_{3} \mathrm{O}-\mathrm{C}_{1}\right), 3.03(1 \mathrm{H}, \mathrm{d}, J=7.0 \mathrm{~Hz}$, $\mathrm{H}-9 \mathrm{a}), 3.02(1 \mathrm{H}, \mathrm{d}, J=14.8 \mathrm{~Hz}, \mathrm{H}-12 \mathrm{~A}), 2.86(1 \mathrm{H}, \mathrm{d}, J=14.8 \mathrm{~Hz}$, H-12B), 2.05-1.95 (2H, m, H-10 $\alpha$, H-11 $\alpha$ ), 1.64-1.56 (2H, m, H$10 \beta, \mathrm{H}-11 \beta) ; \delta_{\mathrm{C}}\left(75 \mathrm{MHz}, \mathrm{CDCl}_{3}\right) 203.37(\mathrm{C} 9), 173.59(\mathrm{COOH})$, 164.70 (C6), 156.73 (C4b), 132.85 (C2), 132.32 (C8a), 132.18 (C3), 124.94 (C8), 115.18 (C7), 110.81 (C5), 79.27 (C1), $55.35\left(\mathrm{CH}_{3} \mathrm{O}-\right.$ $\left.\mathrm{C}_{6}\right), 52.57(\mathrm{C} 9 \mathrm{a}), 50.50\left(\mathrm{CH}_{3} \mathrm{O}-\mathrm{C}_{1}\right), 46.22(\mathrm{C} 4 \mathrm{a}), 40.10(\mathrm{C} 4), 39.74$ (C12), 30.58 (C10), 28.01 (C11); m/z $328\left(\mathrm{M}^{+}, 2 \%\right), 311(0.7), 300$ (1.2), 269 (5), 255 (4), 240 (35), 168 (100), 134 (7), 123 (65), 109 (18), 91 (12), 77 (9), 63 (6).

\section{(1RS,4SR,4a $R S, 9 R S, 9 \mathrm{a} R S)-1,6-D i m e t h o x y-9-h y d r o x y-4-$ methoxy-carbonylmethyl-4,4a,9,9a-tetrahydro-1,4-ethano- $1 H$-fluorene (18)}

A solution of the ketone $\mathbf{1 6}(295 \mathrm{mg}, 0.9 \mathrm{mmol})$ in anhydrous THF $(50 \mathrm{ml})$ was cooled to $0{ }^{\circ} \mathrm{C}$. Lithium triethylborohydride $(1 \mathrm{M}$ in THF, $2.7 \mathrm{ml}, 2.7 \mathrm{mmol}, 3.0$ eq.) was added dropwise. After addition, the reaction mixture was stirred at room temperature for $2 \mathrm{~h}$. Water $(5 \mathrm{ml})$ was then added to decompose the excess of super-hydride. The resulting mixture was diluted with ethyl acetate $(150 \mathrm{ml})$ and washed with water $(50 \mathrm{ml}$, containing $1 \mathrm{M}$ $\mathrm{HCl} 4 \mathrm{ml})$ and brine $(30 \mathrm{ml})$. The aqueous phase was extracted with chloroform $(2 \times 25 \mathrm{ml})$. The combined organic phase was dried over sodium sulfate. After filtration, the solvent was removed and the residue was esterified with an ethereal solution of diazomethane. After removal of the solvent, the residue was purified by flash chromatography on silica gel (petroleum ether 40 $60{ }^{\circ} \mathrm{C}:$ ethyl acetate $\left.=4: 1 \rightarrow 2: 1 \rightarrow 1: 1\right)$ to afford the methyl ester $18(278 \mathrm{mg}, 90 \%)$ as a colourless oil; $v_{\max } / \mathrm{cm}^{-1} 3640(\mathrm{OH}), 3030$ $(\mathrm{ArH}), 2950(\mathrm{CH}), 1730(\mathrm{C}=\mathrm{O}), 1240\left(\mathrm{ArOCH}_{3}\right), 1210(\mathrm{CC}=\mathrm{OC})$, $1130(\mathrm{C}-\mathrm{OH}), 1095(\mathrm{C}-\mathrm{O}), 1000\left(\mathrm{ArOCH}_{3}\right) ; \delta_{\mathrm{H}}\left(300 \mathrm{MHz}, \mathrm{CDCl}_{3}\right)$ $7.25(1 \mathrm{H}, \mathrm{d}, J=8.4 \mathrm{~Hz}, \mathrm{H}-8), 6.83(1 \mathrm{H}, \mathrm{d}, J=2.4 \mathrm{~Hz}, \mathrm{H}-5), 6.78$ $(1 \mathrm{H}, \mathrm{dd}, J=2.4, J=8.4 \mathrm{~Hz}, \mathrm{H}-7), 6.28(1 \mathrm{H}, \mathrm{d}, J=8.8 \mathrm{~Hz}, \mathrm{H}-2)$, $5.53(1 \mathrm{H}, \mathrm{d}, J=8.8 \mathrm{~Hz}, \mathrm{H}-3), 5.24(1 \mathrm{H}, \mathrm{d}, J=8.4 \mathrm{~Hz}, \mathrm{H}-9), 3.73$ $\left(3 \mathrm{H}, \mathrm{s}, \mathrm{CH} \mathrm{H}_{3} \mathrm{O}-\mathrm{C} 6\right), 3.68\left(3 \mathrm{H}, \mathrm{s}, \mathrm{COOCH}_{3}\right), 3.44(1 \mathrm{H}, \mathrm{d}, J=8.4 \mathrm{~Hz}$,
H-4a), 3.42 (3H, s, CH $\left.H_{3} \mathrm{O}-\mathrm{C} 1\right), 2.99$ (1H, dd, $J=8.4, J=8.5 \mathrm{~Hz}$, $\mathrm{H}-9 \mathrm{a}), 2.92(1 \mathrm{H}, \mathrm{d}, J=15.1 \mathrm{~Hz}, \mathrm{H}-12 \mathrm{~A}), 2.84(1 \mathrm{H}, \mathrm{d}, J=15.1 \mathrm{~Hz}$, $\mathrm{H}-12 \mathrm{~B}), 1.85(1 \mathrm{H}, \mathrm{m}, \mathrm{H}-11 \beta), 1.69(2 \mathrm{H}, \mathrm{m}, \mathrm{H}-10 \times 2), 1.40(1 \mathrm{H}, \mathrm{m}$, $\mathrm{H}-11 \alpha) ; \delta_{\mathrm{C}}\left(75 \mathrm{MHz}, \mathrm{CDCl}_{3}\right) 171.99$ (COO), 159.59 (C6), 143.23 (C4b), 137.54 (C8a), 133.53 (C2), 130.67 (C3), 125.67 (C8), 113.51 (C7), 110.57 (C5), 80.34 (C1), 75.70 (C9), 55.10 ( $\left.\mathrm{CH}_{3} \mathrm{O}-\mathrm{C}_{6}\right), 54.32$ (C9a), $51.02\left(\mathrm{COOCH}_{3}\right), 50.94(\mathrm{C} 4 \mathrm{a}), 50.49\left(\mathrm{CH}_{3} \mathrm{O}-\mathrm{C} 1\right), 40.38$ (C4), 40.02 (C12), 31.25 (C10), 27.97 (C11); m/z $344\left(\mathrm{M}^{+}, 10 \%\right)$, 327 (6), 312 (24), 297 (6), 252 (7), 239 (15), 225 (8), 202 (14), 182 (84), 167 (32), 145 (90), 121 (100), 102 (28), 91 (23), 77 (14).

\section{(1SR,2SR,3SR,4RS,4a RS,9RS,9aRS)-1,6-Dimethoxy-2,9- epoxy-3-iodo-4-methoxycarbonylmethyl-2,3,4,4a,9,9a- hexahydro-1,4-ethano- $1 H$-fluorene (19)}

The alcohol 18 (275 $\mathrm{mg}, 0.8 \mathrm{mmol})$ and $N$-iodosuccinimide (225 mg, $1 \mathrm{mmol})$ were dissolved in THF $(25 \mathrm{ml})$. The resulting solution was stirred at room temperature under darkness overnight (14 hours), then diluted with ethyl acetate $(100 \mathrm{ml})$ and washed with $5 \%$ sodium thiosulfate $\left(\mathrm{Na}_{2} \mathrm{~S}_{2} \mathrm{O}_{3}\right)$ aqueous solution $(2 \times$ $30 \mathrm{ml})$ and brine $(30 \mathrm{ml})$. The aqueous phase was extracted with ethyl acetate $(20 \mathrm{ml})$. The combined organic phase was dried over sodium sulfate. After filtration, the solvent was removed under reduced pressure and the residue was purified by flash chromatography on silica gel (petroleum ether 40-60 ${ }^{\circ} \mathrm{C}$ : ethyl acetate $=5: 1 \rightarrow 2: 1 \rightarrow 1: 1)$ to afford the product $19(282 \mathrm{mg}$, $75.3 \%)$ as a colourless oil. Recrystallisation from ethyl acetate solution afforded white crystals; mp $116-117{ }^{\circ} \mathrm{C}$ (from EtOAc); found: C, 51.13\%; H, 4.87\%; I, 26.92\%. Calc. for $\mathrm{C}_{20} \mathrm{H}_{23} \mathrm{O}_{5} \mathrm{I}$ : C, $51.08 \%$; H, 4.93\%; I, 26.98\%; $v_{\max } / \mathrm{cm}^{-1} 3040$ (ArH), $2950(\mathrm{CH})$, $1730(\mathrm{C}=\mathrm{O}), 1250\left(\mathrm{ArOCH}_{3}\right), 1120(\mathrm{C}-\mathrm{O}), 1090(\mathrm{C}-\mathrm{O}), 1030$ $\left(\mathrm{ArOCH}_{3}\right) ; \delta_{\mathrm{H}}\left(300 \mathrm{MHz}, \mathrm{CDCl}_{3}\right) 7.33(1 \mathrm{H}, \mathrm{d}, J=8.2 \mathrm{~Hz}, \mathrm{H}-8)$, $6.97(1 \mathrm{H}, \mathrm{d}, J=2.3 \mathrm{~Hz}, \mathrm{H}-5), 6.81(1 \mathrm{H}, \mathrm{dd}, J=2.3, J=8.3 \mathrm{~Hz}$, H-7), $5.26(1 \mathrm{H}, \mathrm{d}, J=5.0 \mathrm{~Hz}, \mathrm{H}-9), 4.74(1 \mathrm{H}, \mathrm{d}, J=1.5 \mathrm{~Hz}, \mathrm{H}-2)$, $3.93(1 \mathrm{H}, \mathrm{d}, J=8.8 \mathrm{~Hz}, \mathrm{H}-4 \mathrm{a}), 3.78\left(3 \mathrm{H}, \mathrm{s}, \mathrm{CH}_{3} \mathrm{O}-\mathrm{C} 6\right), 3.75(3 \mathrm{H}, \mathrm{s}$, $\left.\mathrm{COOCH}_{3}\right), 3.62(1 \mathrm{H}, \mathrm{s}, \mathrm{H}-3), 3.29\left(3 \mathrm{H}, \mathrm{s}, \mathrm{CH}_{3} \mathrm{O}-\mathrm{C}_{1}\right), 3.08(1 \mathrm{H}$, $\mathrm{ddd}, J=1.5, J=5.0, J=8.8 \mathrm{~Hz}, \mathrm{H}-9 \mathrm{a}), 2.58(1 \mathrm{H}, \mathrm{d}, J=15.2 \mathrm{~Hz}$, H-12A), 2.40 (1H, d, $J=15.2 \mathrm{~Hz}, \mathrm{H}-12 \mathrm{~B}), 2.21-1.98$ (4H, m, $\mathrm{H}-11 \times 2, \mathrm{H}-10 \times 2) ; \delta_{\mathrm{C}}\left(75 \mathrm{MHz}, \mathrm{CDCl}_{3}\right) 171.76(C \mathrm{OO}), 160.44$ (C6), 144.49 (C4b), 136.47 (C8a), 125.98 (C8), 113,75 (C7), 112.14 (C5), 87.53 (C9), 84.73 (C2), 82.97 (C1), 55.31 ( $\left.\mathrm{CH}_{3} \mathrm{O}-\mathrm{C} 6\right), 51.59$ $\left(\mathrm{COOCH}_{3}\right), 50.59(\mathrm{C} 4 \mathrm{a}), 50.29\left(\mathrm{CH}_{3} \mathrm{O}-\mathrm{C} 1\right), 46.63(\mathrm{C} 9 \mathrm{a}), 44.50$ (C3), 41.06 (C4), 38.30 (C12), 30.93 (C10), 18.62 (C11); m/z 470 $\left(\mathrm{M}^{+}, 65 \%\right), 439(8), 411$ (3), 343 (37), 325 (50), 283 (12), 251 (10), 223 (13), 209 (25), 183 (6), 169 (27), 145 (100), 123 (13), 102 (11).

\section{Methyl (1'SR,2' $\left.R S, 4^{\prime} R S, 4 a^{\prime} R S, 9^{\prime} R S, 9 a^{\prime} R S\right)-1^{\prime}, 6^{\prime}$-dimethoxy- $2^{\prime}, 9^{\prime}$-epoxy-2', $3^{\prime}, 4^{\prime}, 4 a^{\prime}, 9^{\prime}, 9 a^{\prime}$-hexahydro-1', $4^{\prime}$-ethano-1' $H$ - fluoren-4'-yl-ethanoate (20)}

The iodide 19 (262.3 mg, $0.56 \mathrm{mmol}$ ) and azobisisobutyronitrile (AIBN) $(5 \mathrm{mg})$ were dissolved in anhydrous THF $(30 \mathrm{ml})$ under a flow of nitrogen. The solution was degassed with nitrogen for 5 minutes then treated with $n-\mathrm{Bu}_{3} \mathrm{SnH}(0.3 \mathrm{ml}, 1.1 \mathrm{mmol}, 2$ eq.). The resulting solution was stirred at reflux with irradiation from a tungsten lamp for $60 \mathrm{~min}$. After removal of the solvent, the residue was purified by flash chromatography on silica gel (petroleum ether $40-60{ }^{\circ} \mathrm{C}$ : ethyl acetate $=2: 1 \rightarrow 1: 1$ ) to afford the product 20 (183 mg, 94.8\%) as a colourless oil. Recrystallisation 
from ethyl acetate afforded colourless crystals; $\mathrm{mp} 98-99^{\circ} \mathrm{C}$ (from EtOAc); found: C, 69.37\%; H, 6.98\%. Calc. for $\mathrm{C}_{20} \mathrm{H}_{24} \mathrm{O}_{5}$ : C, $69.75 \% ; \mathrm{H}, 7.02 \% ; v_{\max } / \mathrm{cm}^{-1} 3005(\mathrm{ArH}), 2950(\mathrm{CH}), 1730(\mathrm{C}=\mathrm{O})$, $1260\left(\mathrm{ArOCH}_{3}\right), 1150(\mathrm{C}-\mathrm{O}), 1085(\mathrm{C}-\mathrm{O}), 1030\left(\mathrm{ArOCH}_{3}\right) ; \delta_{\mathrm{H}}$ $\left(300 \mathrm{MHz}, \mathrm{CDCl}_{3}\right) 7.29(1 \mathrm{H}, \mathrm{d}, J=8.2 \mathrm{~Hz}, \mathrm{H}-8), 6.88(1 \mathrm{H}$, $\mathrm{d}, J=2.2 \mathrm{~Hz}, \mathrm{H}-5), 6.75(1 \mathrm{H}, \mathrm{dd}, J=2.2, J=8.3 \mathrm{~Hz}, \mathrm{H}-7)$, $5.20(1 \mathrm{H}, \mathrm{d}, J=5.0 \mathrm{~Hz}, \mathrm{H}-9), 4.09(1 \mathrm{H}, \mathrm{d}, J=7.2 \mathrm{~Hz}, \mathrm{H}-2)$, $3.73\left(3 \mathrm{H}, \mathrm{s}, \mathrm{CH} \mathrm{H}_{3} \mathrm{O}-\mathrm{C} 6\right), 3.65\left(3 \mathrm{H}, \mathrm{s}, \mathrm{COOCH}_{3}\right), 3.36(1 \mathrm{H}, \mathrm{d}, J=$ $8.8 \mathrm{~Hz}, \mathrm{H}-4 \mathrm{a}), 3.24\left(3 \mathrm{H}, \mathrm{s}, \mathrm{CH}_{3} \mathrm{O}-\mathrm{C} 1\right), 2.98(1 \mathrm{H}, \mathrm{dd}, J=5.0, J=$ $8.7 \mathrm{~Hz}, \mathrm{H}-9 \mathrm{a}), 2.38$ (1H, d, $J=14.4 \mathrm{~Hz}, \mathrm{H}-12 \mathrm{~A}), 2.05(1 \mathrm{H}, \mathrm{d}$, $J=14.4 \mathrm{~Hz}, \mathrm{H}-12 \mathrm{~B}), 1.94(2 \mathrm{H}, \mathrm{m}), 1.80$ (1H, m), $1.61(1 \mathrm{H}, \mathrm{m})$, $1.59(1 \mathrm{H}, \mathrm{dd}, J=7.2, J=14.7 \mathrm{~Hz}, \mathrm{H}-3 \alpha), 1.20(1 \mathrm{H}, \mathrm{dd}, J=2.0$, $J=14.7 \mathrm{~Hz}, \mathrm{H}-3 \beta) ; \delta_{\mathrm{C}}\left(75 \mathrm{MHz}, \mathrm{CDCl}_{3}\right) 171.90$ (COO), 159.83 (C6), 145.75 (C4b), 136.80 (C8a), 125.78 (C8), 113.02 (C7), 111.85 (C5), 83.89 (C9), 82.99 (C1), 77.35 (C2), 55.12 ( $\left.\mathrm{CH}_{3} \mathrm{O}-\mathrm{C} 6\right), 51.31$ (C4a), $51.19\left(\mathrm{COOCH}_{3}\right), 51.00\left(\mathrm{CH}_{3} \mathrm{O}-\mathrm{C} 1\right), 49.86(\mathrm{C} 9 \mathrm{a}), 41.27$ (C3), 40.43 (C4), 34.01 (C12), 32.18 (C10), 18.90 (C11); m/z 344 $\left(\mathrm{M}^{+}, 100 \%\right), 326$ (2), 313 (35), 300 (75), 284 (10), 269 (65), 252 (15), 241 (82), 227 (26), 202 (70), 171 (40), 159 (30), 145 (54), 128 (30), 115 (26), 102 (30), 91 (11).

(1'SR,2' $\left.R S, 4^{\prime} R S, 4 \mathrm{a}^{\prime} R S, 9^{\prime} R S, 9 \mathrm{a}^{\prime} R S\right)-1^{\prime}, 6^{\prime}-\mathrm{Dimethoxy}-2^{\prime}, 9^{\prime}-$ epoxy-2', 3', $4^{\prime}, 4 a^{\prime}, 9^{\prime}, 9 a^{\prime}$-hexahydro-1', $4^{\prime}$-ethano-1' $H$ fluoren-4'-yl-ethanoic acid (21)

The methyl ester 20 (172 mg, $0.5 \mathrm{mmol})$ and potassium hydroxide (560 mg, $10 \mathrm{mmol}, 20$ eq.) were dissolved in ethanol $(12 \mathrm{ml})$ and water $(3 \mathrm{ml})$. The reaction mixture was stirred at room temperature for $6 \mathrm{~h}$. Ice $(80 \mathrm{~g})$ was then added and the mixture was acidified with $1 \mathrm{M} \mathrm{HCl}(15 \mathrm{ml})$ and extracted with chloroform $(5 \times 20 \mathrm{ml})$. The organic phase was dried over sodium sulfate. After filtration, the solvent was removed under reduced pressure and the residue was purified by flash chromatography on silica gel (ethyl acetate) to afford the acid 21 (153 mg, 92.7\%), after recrystallisation from ethyl acetate, as colourless needles; mp $189-190{ }^{\circ} \mathrm{C}$ (from EtOAc); found: $\mathrm{C}, 68.65 \% ; \mathrm{H}, 6.67 \%$. Calc. for $\mathrm{C}_{19} \mathrm{H}_{22} \mathrm{O}_{5}$ : C, 69.07\%; $\mathrm{H}$, $6.71 \% ; v_{\max } / \mathrm{cm}^{-1} 3500(\mathrm{OH}), 3000(\mathrm{ArH}), 2950(\mathrm{CH}), 1705(\mathrm{C}=\mathrm{O})$, $1248\left(\mathrm{ArOCH}_{3}\right), 1200(\mathrm{C}-\mathrm{O}), 1085\left(\mathrm{ArOCH}_{3}\right), 1030\left(\mathrm{ArOCH}_{3}\right)$; $\delta_{\mathrm{H}}\left(300 \mathrm{MHz}, \mathrm{CDCl}_{3}\right) 7.35(1 \mathrm{H}, \mathrm{d}, J=8.2 \mathrm{~Hz}, \mathrm{H}-8), 6.92(1 \mathrm{H}$, $\mathrm{d}, J=2.2 \mathrm{~Hz}, \mathrm{H}-5), 6.79(1 \mathrm{H}, \mathrm{dd}, J=2.2, J=8.2 \mathrm{~Hz}, \mathrm{H}-7)$, $5.27(1 \mathrm{H}, \mathrm{d}, J=5.1 \mathrm{~Hz}, \mathrm{H}-9), 4.17(1 \mathrm{H}, \mathrm{d}, J=7.2 \mathrm{~Hz}, \mathrm{H}-2)$, $3.77\left(3 \mathrm{H}, \mathrm{s}, \mathrm{CH}_{3} \mathrm{O}-\mathrm{C} 6\right), 3.65\left(3 \mathrm{H}, \mathrm{s}, \mathrm{COOCH}_{3}\right), 3.44(1 \mathrm{H}, \mathrm{d}, J=$ $8.8 \mathrm{~Hz}, \mathrm{H}-4 \mathrm{a}), 3.28\left(3 \mathrm{H}, \mathrm{s}, \mathrm{CH}_{3} \mathrm{O}-\mathrm{C} 1\right), 3.03(1 \mathrm{H}, \mathrm{dd}, J=5.0, J=$ $8.8 \mathrm{~Hz}, \mathrm{H}-9 \mathrm{a}), 2.47$ (1H, d, $J=14.5 \mathrm{~Hz}, \mathrm{H}-12 \mathrm{~A}), 2.12(1 \mathrm{H}, \mathrm{d}$, $J=14.5 \mathrm{~Hz}, \mathrm{H}-12 \mathrm{~B}), 1.98(3 \mathrm{H}, \mathrm{m}), 1.70(1 \mathrm{H}, \mathrm{m}), 1.67$ (1H, dd, $J=7.2, J=15.2 \mathrm{~Hz}, \mathrm{H}-3 \alpha), 1.25(1 \mathrm{H}, \mathrm{dd}, J=2.5, J=15.2 \mathrm{~Hz}$, $\mathrm{H}-3 \beta) ; \delta_{\mathrm{C}}\left(75 \mathrm{MHz}, \mathrm{CDCl}_{3}\right) 174.15$ (COO), 159.94 (C6), 145.88 (C4b), 136.41 (C8a), 125.83 (C8), 113.17 (C7), 111.96 (C5), 84.06 (C9), 83.23 (C1), 77.51 (C2), 55.14 ( $\left.\mathrm{CH}_{3} \mathrm{O}-\mathrm{C} 6\right), 51.25$ (C4a), 50.95 $\left(\mathrm{CH}_{3} \mathrm{O}-\mathrm{C} 1\right), 49.80(\mathrm{C} 9 \mathrm{a}), 41.13(\mathrm{C} 3), 40.46(\mathrm{C} 4), 33.77$ (C12), 31.98 (C10), 18.86 (C11); $m /$ z $330\left(\mathrm{M}^{+}, 100 \%\right), 312(2), 298(4), 286(60)$, 270 (14), 255 (50), 241 (60), 227 (12), 211 (16), 202 (74), 171 (18), 158 (34), 145 (24), 128 (10), 102 (11), 79 (5).

\section{(1SR,2RS,4RS,4a $R S, 9 R S, 9 \mathrm{a} R S)-4-\left(3^{\prime}\right.$-Diazo-2'-oxopropyl)- 1,6-dimethoxy-2,9-epoxy-2,3,4,4a,9,9a-hexahydro-1, 4-ethano-1 $H$-fluorene (10)}

Sodium hydride (60\% in mineral oil, $80 \mathrm{mg}, 2 \mathrm{mmol}, 6$ eq.) was washed with anhydrous THF (3 times). The acid 21 (110 mg,
$0.33 \mathrm{mmol})$ in THF $(8 \mathrm{ml})$ was then added via a cannula and washed with THF $(6 \mathrm{ml})$. The resulting suspension was stirred at ambient temperature for $20 \mathrm{~min}$. DMF (160 $\mu \mathrm{l}, 2 \mathrm{mmol}, 6$ eq.) was added, followed by oxalyl chloride $(180 \mu 1,2.1 \mathrm{mmol}, 6$ eq.) at $0{ }^{\circ} \mathrm{C}$. The reaction mixture was stirred at room temperature under nitrogen for $20 \mathrm{~h}$, then carefully filtered into an ethereal diazomethane solution at $0{ }^{\circ} \mathrm{C}$. The reaction was allowed to proceed at room temperature for $30 \mathrm{~min}$. The resulting mixture was filtered through a short column of silica gel and washed with ethyl acetate. After removal of the solvent, the residue was purified by flash chromatography on silica gel (petroleum ether $40-60{ }^{\circ} \mathrm{C}$ : ethyl acetate $=2: 1 \rightarrow 1: 1 \rightarrow 1: 2 \rightarrow 0: 1)$ to yield the diazo ketone 10 (88 mg, 74.6\%) as a yellow oil; $v_{\max } / \mathrm{cm}^{-1} 3000(\mathrm{ArH})$, $2950(\mathrm{CH}), 2110\left(\mathrm{CHN}_{2}\right), 1670(\mathrm{C}=\mathrm{O}) ; \delta_{\mathrm{H}}\left(300 \mathrm{MHz}, \mathrm{CDCl}_{3}\right) 7.34$ $(1 \mathrm{H}, \mathrm{d}, J=8.2 \mathrm{~Hz}, \mathrm{H}-8), 6.92(1 \mathrm{H}, \mathrm{d}, J=2.4 \mathrm{~Hz}, \mathrm{H}-5), 6.78(1 \mathrm{H}$, $\mathrm{dd}, J=2.4, J=8.2 \mathrm{~Hz}, \mathrm{H}-7), 5.24(1 \mathrm{H}, \mathrm{d}, J=5.1 \mathrm{~Hz}, \mathrm{H}-9)$, $5.20\left(1 \mathrm{H}\right.$, br s, $\left.\mathrm{CHN}_{2}\right), 4.12(1 \mathrm{H}, \mathrm{d}, J=7.2 \mathrm{~Hz}, \mathrm{H}-2), 3.77(3 \mathrm{H}, \mathrm{s}$, $\left.\mathrm{CH}_{3} \mathrm{O}-\mathrm{C} 6\right), 3.47$ (1H, d, $\left.J=8.8 \mathrm{~Hz}, \mathrm{H}-4 \mathrm{a}\right), 3.28\left(3 \mathrm{H}, \mathrm{s}, \mathrm{CH}_{3} \mathrm{O}-\right.$ C1), $3.01(1 \mathrm{H}$, ddd, $J=1.5, J=5.1, J=8.8 \mathrm{~Hz}, \mathrm{H}-9 \mathrm{a}), 2.38$ $(1 \mathrm{H}, \mathrm{d}, J=14.4 \mathrm{~Hz}, \mathrm{H}-12 \mathrm{~A}), 2.04$ (1H, d, $J=14.4 \mathrm{~Hz}, \mathrm{H}-12 \mathrm{~B})$, $1.96(3 \mathrm{H}, \mathrm{m}), 1.64(2 \mathrm{H}, \mathrm{m}), 1.20(1 \mathrm{H}, \mathrm{dd}, J=2.5, J=14.7 \mathrm{~Hz}$, $\mathrm{H}-3 \beta) ; \delta_{\mathrm{C}}\left(75 \mathrm{MHz}, \mathrm{CDCl}_{3}\right) 193.45$ (CO), 159.94 (C6), 146.12 (C4b), 136.98 (C8a), 125.95 (C8), 113.14 (C7), 112.24 (C5), 84.04 (C9), 83.14 (C1), $77.64(\mathrm{C} 2), 55.41\left(\mathrm{CH}_{3} \mathrm{O}-\mathrm{C} 6\right), 55.37\left(\mathrm{CHN}_{2}\right)$, $51.83\left(\mathrm{CH}_{3} \mathrm{O}-\mathrm{C} 1\right), 51.18$ (C4a), 50.02 (C9a), 44.48 (C12), 41.57 (C3), 35.12 (C10), 32.28 (C4), 19.08 (C11); m/z 354 (M+, 4\%), 326 (100), 298 (51), 283 (20), 270 (17), 251 (35), 241 (80), 223 (44), 202 (58), 171 (37), 158 (52), 146 (76), 128 (33), 102 (34), 91 (20), $71(27)$.

\section{(3aSR,5SR,5a $R S, 6 R S, 10 \mathrm{~b} R S, 10 \mathrm{c} R S, 10 \mathrm{e} R S)-5,9-\mathrm{Dimethoxy}-$ 6,11-epoxy-2-oxo-2,3,3a,4,5,5a,6,10b-octahydro-5,10c-ethano- $1 H$-cyclopenta[c]-fluorene (22)}

A solution of diazoketone $\mathbf{1 0}(3 \mathrm{mg}, 0.0085 \mathrm{mmol})$ in dichloromethane $(2 \mathrm{ml})$ was added to a suspension of $\mathrm{Rh}_{2}$ (mandelate $)_{4}(0.2 \mathrm{mg})$ in dichloromethane $(2 \mathrm{ml})$ at reflux. After the addition, the resulting mixture was stirred at reflux for a further 10 min. One drop of DBU was added and stirring was continued for another $2 \mathrm{~min}$. After removal of the solvent, the residue was purified by flash chromatography on silica gel (ethyl acetate) to afford an inseparable mixture of $\mathrm{C}-\mathrm{H}$ insertion products ( $3 \mathrm{a} \alpha$ : $3 \mathrm{a} \beta=2: 1 ; 1.3 \mathrm{mg}, 46.9 \%$ ) as a colourless oil.

Major isomer. $\delta_{\mathrm{H}}\left(300 \mathrm{MHz}, \mathrm{CDCl}_{3}\right) 7.38(1 \mathrm{H}, \mathrm{d}, J=8.3 \mathrm{~Hz}$, H-7), 6.82 (1H, dd, $J=2.3, J=8.3 \mathrm{~Hz}, \mathrm{H}-8), 6.62(1 \mathrm{H}, \mathrm{d}, J=$ $2.3 \mathrm{~Hz}, \mathrm{H}-10), 5.27$ (1H, d, $J=5.4 \mathrm{~Hz}, \mathrm{H}-6), 4.34$ (1H, d, $J=$ $8.5 \mathrm{~Hz}, \mathrm{H}-11 \alpha), 3.79$ (3H, s, $\left.\mathrm{CH}_{3} \mathrm{O}-\mathrm{C} 9\right), 3.33$ (3H, s, $\left.\mathrm{CH}_{3} \mathrm{O}-\mathrm{C} 5\right)$, $3.11(1 \mathrm{H}, \mathrm{dd}, J=1.8, J=8.7 \mathrm{~Hz}, \mathrm{H}-10 \mathrm{~b}), 3.02(1 \mathrm{H}, \mathrm{ddd}, J=1.7$, $J=5.4, J=8.7 \mathrm{~Hz}, \mathrm{H}-5 \mathrm{a}), 2.70-2.55$ (2H, m), 2.45-2.30 (2H, m), $2.25(1 \mathrm{H}, \mathrm{m}), 1.93-1.60(3 \mathrm{H}, \mathrm{m}), 1.54(1 \mathrm{H}, \mathrm{ddd}, J=2.0, J=8.5$, $J=13.9 \mathrm{~Hz}, \mathrm{H}-12 \alpha)$.

Minor isomer. $\delta_{\mathrm{H}}\left(300 \mathrm{MHz}, \mathrm{CDCl}_{3}\right) 7.38(1 \mathrm{H}, \mathrm{d}, J=8.3 \mathrm{~Hz}$, H-7), $6.82(1 \mathrm{H}, \mathrm{dd}, J=2.3, J=8.3 \mathrm{~Hz}, \mathrm{H}-8), 6.62(1 \mathrm{H}, \mathrm{d}, J=$ $2.3 \mathrm{~Hz}, \mathrm{H}-10), 5.36(1 \mathrm{H}, \mathrm{d}, J=5.4 \mathrm{~Hz}, \mathrm{H}-6), 4.13(1 \mathrm{H}, \mathrm{dd}, J=1.7$, $J=8.5 \mathrm{~Hz}, \mathrm{H}-11 \alpha), 3.79\left(3 \mathrm{H}, \mathrm{s}, \mathrm{CH}_{3} \mathrm{O}-\mathrm{C} 9\right), 3.32\left(3 \mathrm{H}, \mathrm{s}, \mathrm{CH}_{3} \mathrm{O}-\right.$ C5), $3.22(1 \mathrm{H}, \mathrm{dd}, J=1.8, J=8.7 \mathrm{~Hz}, \mathrm{H}-8), 3.16(1 \mathrm{H}, \mathrm{ddd}, J=$ $1.7, J=5.4, J=8.7 \mathrm{~Hz}, \mathrm{H}-5 \mathrm{a}), 2.90-1.50(9 \mathrm{H}, \mathrm{m})$. 


\section{(2RS,3RS,3a RS,10a $R S, 10 \mathrm{~b} R S)-3,7-D i m e t h o x y-2,4-\mathrm{epoxy-}$ 1,2,3,3a,4,5-hexahydro- $10 H, 10 \mathrm{~b} H-3,10 \mathrm{a}-$ ethanocyclohept $\mid b c]-$ acenaphthylen-9-one (23)}

A solution of the diazoketone $10(21 \mathrm{mg}, 0.06 \mathrm{mmol})$ in toluene $(5 \mathrm{ml})$ was added dropwise to a solution of copper(II) bis( $N$-tertbutylsalicylaldiminato) $(3 \mathrm{mg})$ in toluene $(3 \mathrm{ml})$ at reflux. After the addition, the resulting mixture was stirred at reflux for a further $15 \mathrm{~min}$. The reaction mixture was cooled to room temperature and one drop of DBU was added. After stirring for $30 \mathrm{~min}$ at $40{ }^{\circ} \mathrm{C}$ (oil bath), the solvent was removed and the residue was purified by flash chromatography on silica gel (petroleum ether $40-60{ }^{\circ} \mathrm{C}$ : ethyl acetate $=1: 1 \rightarrow 1: 5 \rightarrow 0: 1)$ to afford the product 23 $(5.8 \mathrm{mg}, 30 \%)$ as a yellow oil; $v_{\max } / \mathrm{cm}^{-1} 2924(\mathrm{CH}), 1730(\mathrm{C}=\mathrm{O})$, $1660(\mathrm{C}=\mathrm{O}), 1245(\mathrm{CC}=\mathrm{OC}) ; \delta_{\mathrm{H}}\left(300 \mathrm{MHz}, \mathrm{CDCl}_{3}\right) 5.91(1 \mathrm{H}, \mathrm{s}$, $\mathrm{H}-8), 5.44$ (1H, dd, $J=2.6, J=5.6 \mathrm{~Hz}, \mathrm{H}-6), 4.89(1 \mathrm{H}, \mathrm{d}, J=$ $3.7 \mathrm{~Hz}, \mathrm{H}-4), 4.07(1 \mathrm{H}, \mathrm{d}, J=5.0 \mathrm{~Hz}, \mathrm{H}-2 \alpha), 3.50\left(3 \mathrm{H}, \mathrm{s}, \mathrm{CH}_{3} \mathrm{O}-\right.$ C7), $3.30\left(3 \mathrm{H}, \mathrm{s}, \mathrm{CH}_{3} \mathrm{O}-\mathrm{C} 3\right), 3.11(1 \mathrm{H}, \mathrm{d}, J=10.2 \mathrm{~Hz}, \mathrm{H}-10 \mathrm{~b}), 3.01$ $(1 \mathrm{H}, \mathrm{m}, \mathrm{H}-5 \alpha), 2.87(1 \mathrm{H}, \mathrm{dd}, J=3.8, J=9.9 \mathrm{~Hz}, \mathrm{H}-3 \mathrm{a}), 2.10-1.85$ $(3 \mathrm{H}, \mathrm{m}), 1.70-1.45(6 \mathrm{H}, \mathrm{m}) ; \delta_{\mathrm{C}}\left(75 \mathrm{MHz}, \mathrm{CDCl}_{3}\right) 197.37(\mathrm{C} 9, \mathrm{CO})$, 155.47 (C7), 148.49 (C4a), 143.76 (C10c), 130.04 (C8a), 120.77 (C8), 94.75 (C6), 84.55 (C4), 83.67 (C3), 78.32 (C2), $55.82\left(\mathrm{CH}_{3} \mathrm{O}-\right.$ C7), 50.29 (C10b), 49.39 ( $\left.\mathrm{CH}_{3} \mathrm{O}-\mathrm{C} 3\right), 47.43$ (C10a), 45.57 (C3a), 38.69 (C12), 34.16 (C11), 33.99 (C10), 32.00 (C5), 19.18 (C1); $m / z$ $326\left(\mathrm{M}^{+}, 94 \%\right), 325$ (100), 310 (7), 295 (8), 281 (14), 265 (20), 249 (44), 237 (20), 224 (65), 211 (24), 178 (10), 167 (7), 158 (23), 139 (9), 128 (11), 115 (18), 91 (5), 71 (10).

\section{Notes and references}

1 J. G. Buta, J. L. Flippen and W. L. Lusby, J. Org. Chem., 1978, 43, 1002.
2 N. Sun, Z. Xue, X. Liang and L. Huang, Acta. Pharm. Sin., 1979, 14, 39.

3 J. Du, C. M.-H and R.-L. Nie, J. Nat. Prod., 1999, 62, 1664.

4 S. Kang, S. Cai and L. Teng, Acta. Pharm. Sin., 1981, 16, 867.

5 B. Frey, L. N. Mander and D. C. R. Hockless, J. Chem. Soc., Perkin Trans. 1, 1998, 1555

6 D. H. Rogers, B. Frey, F. S. Roden, F.-W. Russkamp, A. C. Willis and L. N. Mander, Aust. J. Chem., 1999, 52, 1093.

7 B. Frey, A. P. Wells, F. S. Roden, T. D. Au, D. C. R. Hockless, A. C. Willis and L. N. Mander, Aust. J. Chem., 2000, 53, 819.

8 J. Koo, J. Am. Chem. Soc., 1953, 75, 1891.

9 G. H. Posner, A. Haces, W. Harrison and C. M. Kitner, J. Org. Chem., 1987, 52, 4836.

10 M. P. Doyle, V. Bagheri, T. J. Wandless, N. K. Harn, D. A. Brinker, C. T. Eagle and K.-L. Loh, J. Am. Chem. Soc., 1990, 112, 1906.

11 J. C. Morris, L. N. Mander and D. C. R. Hockless, Synthesis, 1998, 455.

12 E. J. Corey and A. G. Myers, J. Am. Chem. Soc., 1985, 107, 5574.

13 H. Zhang, D. C. Appels, D. C. R. Hockless and L. N. Mander, Tetrahedron Lett., 1998, 39, 6577.

14 L. N. Mander and T. P. O’Sullivan, Synlett, 2003, 9, 1367.

15 J. Fried and R. C. Elderfield, J. Org. Chem., 1941, 6, 577.

16 D. B. Dess and J. C. Martin, J. Org. Chem., 1983, 48, 4155.

17 E. Fujita, M. Node, K. Nishide, M. Sai and K. Fuji, J. Org. Chem., 1980, 46, 1991.

18 A. Padwa, Acc. Chem. Res., 1991, 24, 22.

19 Padwa, D. J. Austin, A. T. Price, M. A. Semones, M. P. Doyle, N. M. Protopopova, W. R. Winchester and A. Tran, J. Am. Chem. Soc., 1993, 1993, 8669

20 Abad, C. Agulló, M. Arnó, M. L. Marin and R. J. Zaragozá, Synlett, 1997, 574.

21 Chapleo, P. Hallet, B. Lythgoe, I. Waterhouse and P. Wright, J. Chem. Soc., Perkin Trans. 1, 1977, 1211.

22 R. Noyori, M. Suzuki and T. Tsunoda, Tetrahedron Lett., 1980, 21, 1357.

23 M. S. Newman and J. O. Landers, J. Org. Chem., 1976, 42, 2556.

24 K.-F. Chiu, PhD Thesis, Australian National University, 1986. 